Journal of Horticultural Science \& Biotechnology

\title{
Effects of compost and defatted oilseed meals as sustainable organic fertilizer on Cardoon (Cynara Cardunculus L.) production in the Mediterranean basin
}

\begin{tabular}{|c|c|}
\hline Journal: & The Journal of Horticultural Science \& Biotechnology \\
\hline Manuscript ID & THSB-2018-0206 \\
\hline Manuscript Type: & Original Article \\
\hline Date Submitted by the Author: & 29-May-2018 \\
\hline Complete List of Authors: & $\begin{array}{l}\text { Ronga, Domenico; University of Modena and Reggio Emilia, Department of } \\
\text { Life Sciences } \\
\text { Villecco, Domenica ; Council for Agricultural Research and Economics - } \\
\text { Research Centre for Vegetable and Ornamental Crops } \\
\text { Zaccardelli, Massimo; Council for Agricultural Research and Economics - } \\
\text { Research Centre for Vegetable and Ornamental Crops }\end{array}$ \\
\hline Keywords: & $\begin{array}{l}\text { cardoon, organic fertlizers, sustainability, biomass production, energy crop, } \\
\text { global worming potential }\end{array}$ \\
\hline Abstract: & 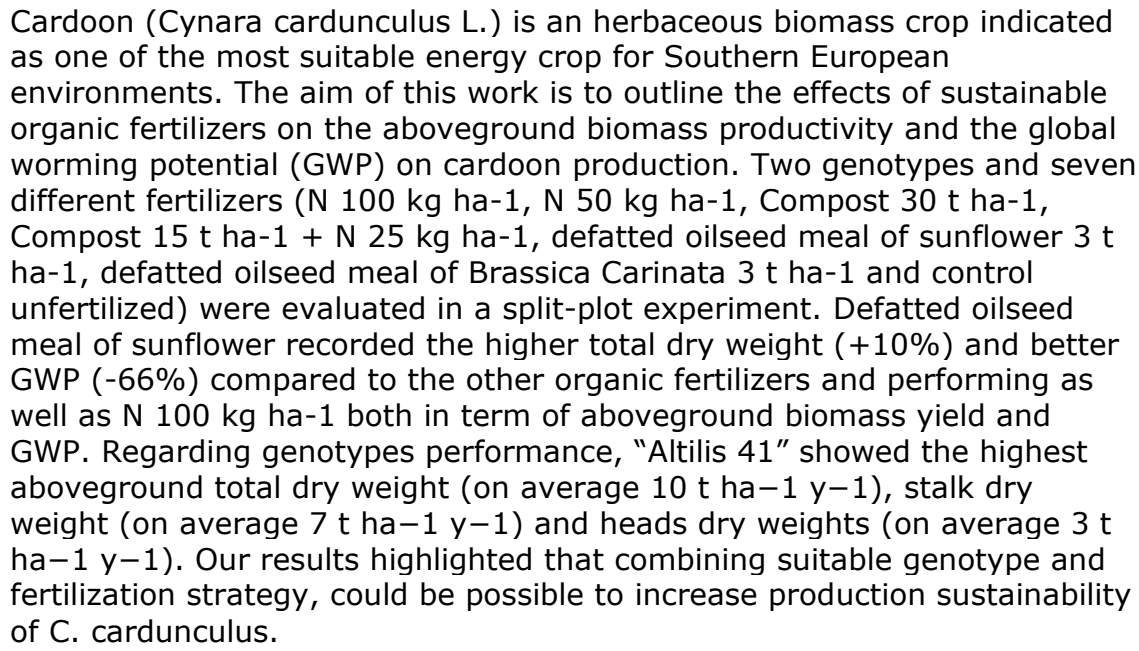 \\
\hline
\end{tabular}

\section{SCHOLARONE \\ Manuscripts}




\begin{abstract}
Dear Editor, please consider the enclosed manuscript Effects of compost and defatted oilseed meals as sustainable organic fertilizer on Cardoon (Cynara Cardunculus L.) production in the Mediterranean basin for publication in The Journal of Horticultural Science and Biotechnology.
\end{abstract}

The present manuscript investigates the effects of sustainable organic fertilizers on the aboveground biomass productivity and the global worming potential (GWP) on cardoon production, over three years of cultivation in the rain fed and temperate climate conditions of Southern Italy. Two genotypes of $C$. cardunculus var. altilis D.C. cv. "Gobbo di Nizza" and "Altilis 41" were compared as energy crops. Seven different fertilizers (N $100 \mathrm{~kg} \mathrm{ha}^{-1}, \mathrm{~N} 50 \mathrm{~kg} \mathrm{ha}^{-1}$, Compost $30 \mathrm{t} \mathrm{ha}^{-1}$, Compost $15 \mathrm{tha}^{-1}$ $+\mathrm{N} 25 \mathrm{~kg} \mathrm{ha}^{-1}$, defatted oilseed meal of sunflower $3 \mathrm{tha}^{-1}$, defatted oilseed meal of Brassica Carinata $3 \mathrm{t} \mathrm{ha}^{-1}$ and control unfertilized) were evaluated in a split-plot experiment. This is significant because nowadays farmers are called to increase the agricultural sustainability and few published paper reported the effects of fertilizers on cardoon production. We believe that this manuscript is appropriate for publication by The Journal of Horticultural Science and Biotechnology because it might contribute in the improvement of cardoon productivity and sustainability.

This manuscript is an unpublished work. 


\begin{abstract}
Authors: Domenico Ronga ${ }^{\mathrm{a}}$, Domenica Villecco ${ }^{\mathrm{b}}$, Massimo Zaccardelli ${ }^{\mathrm{b}}$.
${ }^{a}$ Interdepartmental Research Centre BIOGEST-SITEIA, University of Modena and Reggio Emilia, Piazzale Europa 1, 42124 Reggio Emilia (RE), Italy

${ }^{\mathrm{b}}$ Council for Agricultural Research and Economics - Research Centre for Vegetable and Ornamental Crops, Via Cavalleggeri, 25, 84098 Pontecagnano (SA), Italy.

Corresponding author for this article is Dr Domenico Ronga at Department of Life Sciences, University of Modena and Reggio Emilia, Via Amendola 2 - Padiglione Besta, 42122 Reggio Emilia, Italy, Tel.: +390522522064, fax: +390522522027, email address: domenico.ronga@unimore.it
\end{abstract}

The authors mutually agree that it should be submitted to The Journal of Horticultural Science and Biotechnology.

It is the original work of the authors.

The manuscript was not previously submitted to The Journal of Horticultural Science and Biotechnology and is not under consideration for publication in any other journal. Thank you for your consideration of this manuscript.

\author{
Yours Sincerely
}

Domenico Ronga 


\section{Effects of compost and defatted oilseed meals as sustainable organic fertilizer on}

\section{Cardoon (Cynara Cardunculus L.) production in the Mediterranean basin}

3 Domenico Ronga*a $^{* a}$, Domenica Villecco ${ }^{\mathrm{b}}$ and Massimo Zaccardelli ${ }^{\mathrm{b}}$

$4 \quad{ }^{\mathrm{a}}$ Interdepartmental Research Centre BIOGEST-SITEIA, University of Modena and Reggio Emilia,

5 Piazzale Europa 1, 42124 Reggio Emilia, Italy

$6 \quad{ }^{\mathrm{b}}$ Council for Agricultural Research and Economics - Research Centre for Vegetable and Ornamental

7 Crops, Via Cavalleggeri, 25, 84098 Pontecagnano (SA), Italy.

8 *corresponding author: Department of Life Science, University of Modena and Reggio Emilia, via

9 Amendola 2, 42122 Reggio Emilia, Italy.

10 e-mail address: domenico.ronga@unimore.it

11 Abstract

12 Cardoon (Cynara cardunculus L.) is an herbaceous biomass crop indicated as one of the most suitable 13 energy crop for Southern European environments. The aim of this work is to outline the effects of sustainable organic fertilizers on the aboveground biomass productivity and the global worming potential (GWP) on cardoon production, over three years of cultivation in the rain fed and temperate climate conditions of Southern Italy. Two genotypes of C. cardunculus var. altilis D.C. cv. "Gobbo di Nizza" and "Altilis 41", were compared as energy crops. Seven different fertilizers (N $100 \mathrm{~kg} \mathrm{ha}^{-1}, \mathrm{~N}$ $50 \mathrm{~kg} \mathrm{ha}^{-1}$, Compost $30 \mathrm{tha}^{-1}$, Compost $15 \mathrm{tha}^{-1}+\mathrm{N} 25 \mathrm{~kg} \mathrm{ha}^{-1}$, defatted oilseed meal of sunflower $3 \mathrm{t}$ $\mathrm{ha}^{-1}$, defatted oilseed meal of Brassica Carinata $3 \mathrm{tha}^{-1}$ and control unfertilized) were evaluated in a split-plot experiment. C. cardunculus was affected by the different nitrogen fertilization treatments both in term of aboveground biomass yield and GWP. Defatted oilseed meal of sunflower recorded the higher total dry weight $(+10 \%)$ and better GWP $(-66 \%)$ compared to the other organic fertilizers and performing as well as $\mathrm{N} 100 \mathrm{~kg} \mathrm{ha}^{-1}$ both in term of aboveground biomass yield and GWP. Regarding genotypes performance, "Altilis 41 " showed the highest aboveground total dry weight (on average $10 \mathrm{t}$ $\mathrm{ha}^{-1} \mathrm{y}^{-1}$ ), stalk dry weight (on average $7 \mathrm{tha}^{-1} \mathrm{y}^{-1}$ ) and heads dry weights (on average $3 \mathrm{tha}^{-1} \mathrm{y}^{-1}$ ). Finally, over the 3 -years of cultivation C. cardunculus yielded from $12 \mathrm{t} \mathrm{ha}^{-1}$ of total aboveground 
27 biomass dry weight in the first year decreasing to $6.0 \mathrm{t} \mathrm{ha}^{-1}$ of the total aboveground biomass dry 28 weight in the third one. Our results highlighted that combining suitable genotype and fertilization 29 strategy, could be possible to increase production sustainability of $C$. cardunculus as energy crop in the 30 Mediterranean area.

32 Keywords: cardoon, organic fertilizers, sustainability, biomass production, energy crop, global 33 worming potential

\section{1. INTRODUCTION}

36 An increase of the crop production sustainability is one of the challenges proposed by the European 37 Community to reduce the dependence on oil consumption, which could improve the security of energy 38 supply in the medium and long term (Mantineo, D’agosta, Copani, Patanè, \& Cosentino, 2009). 39 Biomasses used to obtain green energy on a global scale, can contribute to improve the environment 40 sustainability. In fact, when biomasses are burned, they emitted carbon into the atmosphere that 41 previously was adsorbed during the crop cycle in the photosynthetic process (Royal Society, 2008).

42 Different biomasses can be used in the EU to obtain green energy, such as those from arable crops 43 currently grown for food: sugar, starch and oil crops, forestry or domestic waste and marine biomass.

44 On the other hand, using dedicated crops, called "energy crops", which were bred to produce huge 45 biomass, could be possible favor their use for energy production (Mantineo, 2009) preserving the crops 46 cultivated to feed human and animals.

47 The use of energy crops presupposes that the obtained energy is significantly higher than that required 48 to grow, according to Lewandowski \& Schmidt (2006).

49 Simple cropping techniques and low productions costs are the main requirements to produce energy 50 crops; cardoon (Cynara cardunculus L.) is indicated as one of the most suitable for satisfying these 51 requirements in the Mediterranean area (González, González-García, Ramiro, González, Sabio, Gañán, 52 \& Rodríguez, 2004). 
53 Cultivated cardoon (Cynara Cardunculus L. var. altilis DC) belongs, together with globe artichoke $(C$. 54 cardunculus L. var. scolymus L.) and wild cardoon (C. cardunculus L. var. sylvestris (Lamk) Fiori), to 55 the family Asteraceae. Cardoon is an herbaceous plant with polyannual cycle suitable for the 56 Mediterranean basin (Portis, Barchi, Acquadro, Macua, \& Lanteri, 2005). Cultivated cardoon is raised 57 from seed and handled as an annual plant. Seeds are sown in late Spring and the plants over-summer in 58 the vegetative state (Portis et al., 2005). The European agricultural area devoted to this crop $(2,000-$ 593,000 ha) is mainly confined to a small area and in particularly in Spain, Italy, France and Greece, 60 where it is used for the preparation of traditional foods (Ierna \& Mauromicale, 2010; Portis et al., $612005)$.

62 In recent years, the species $C$. cardunculus has been considered as multipurpose crop. Several 63 researches have indicated that cardoon is among the most promising species for energy and cellulose 64 production in the Mediterranean basin (Foti \& Cosentino, 2001; Cosentino, Copani, Mantineo, Patané, 65 \& D’Agosta, 2008). In fact, C. cardunculus offer a wide spectrum of different biomass uses: for 66 alternative energy production by combustion, pyrolysis and gasification (Gonzàles et al., 2004; Ochoa 67 \& Fandos, 2004); for paper pulp (Gominho, Fernandez, \& Pereira, 2001) and for feeding ruminants 68 (Cajarville, Gonzalez, Repetto, Rodrìguez, \& Martìnez, 1999). Moreover, achens contains oil (25-33\%) 69 with high levels of $\alpha$-tocopherol, which offers stability against oxidation (Maccarone et al., 1999). 70 These characteristics make C. cardunculus oil suitable for human consumption. Furthermore, research 71 has been carried out to obtain biodiesel from C. cardunculus oil (Lapuerta, Armas, Ballesteros, \& 72 Fenàndez, 2005). After oil extraction from the seeds, the residual meal could be used for animal feed 73 (Foti et al., 1999). C. cardunculus L. has also been used for medicinal purposes (Kraft, 1997) due to its 74 richness of polyphenols and inuline into the leaves (Jimenez-Escrig, Dragsted, Daneshvar, Pulido, \& 75 Saura-Calixto, 2003).

76 The aboveground biomass yield in term of dry weight is, on average, $19.0 \mathrm{t} \mathrm{ha}^{-1}$ (Foti et al., 1999;

77 Maccarone et al., 1999). Moreover, other studies reported that the yield expressed as total energy 78 obtainable by 1 ha of crop, is greater for cultivated var. altilis (cardoon genotypes) compared to var. 
79 scolymus (globe artichoke) and var. sylvestris (wild cardoon) (Raccuia \& Melilli, 2007; Angelini,

80 Ceccarini, Nassi o Di Nasso, \& Bonari, 2009).

81 Several works carried out in Italy reported an interesting potential yield in terms of biomass and energy

82 of C. cardunculus (Angelini et al., 2009; Piscioneri, Sharma, Baviello, \& Orlandini, 2000; Gherbin,

83 Monteleone, \& Tarantino, 2001; Mantineo et al., 2009; Ierna \& Mauromicale, 2010); nonetheless,

84 information on cropping techniques and crop performances showed great variability.

85 Regarding fertilization, some authors (Mantineo et al., 2009; Ierna \& Mauromicale, 2010; González et 86 al., 2004; Grammelis, Malliopoulou, Basinas, \& Danalatos, 2008) investigated the effects of different 87 chemical nitrogen applications on yield performances of cultivated cardoons. However, to the author's

88 knowledge, there is lack of information on the effects of organic fertilizers on cardoon production in 89 literature and, from this point of view, a more comprehensive assessment might be useful to increase 90 the sustainability of this crop. Therefore, we evaluated the effects of compost and two different defatted 91 oilseed meals applied as organic fertilizers to cardoon production under over 3-years of Mediterranean 92 climatic conditions. Assessments included effects of fertilizers on the traits influencing the yield 93 component, aboveground biomass yield and environmental impact.

\section{2. MATERIALS AND METHODS}

\section{2.1 Location of the trial}

98 The agronomic performance of two cultivated cardoon varieties was evaluated in an open field trial at 99 Sele Valley $\left(40^{\circ} 35^{\prime} 03.8^{\prime \prime N}, 14^{\circ} 58^{\prime} 48.6^{\prime \prime E}\right)$ (Salerno, Southern Italy) during the 3 -year periods in a 100 Typic Haploxerepts soil (Soil Taxonomy, USDA). The physical and chemical soil properties were as 101 follows: sand $26.8 \%$, silt $40.8 \%$, clay $32.4 \%$, limestone $2.4 \%$, pH 7.8 , organic matter $1.6 \%$, total 102 nitrogen $1.3 \%, \mathrm{P}_{2} \mathrm{O}_{5} 126 \mathrm{mg} \mathrm{kg}^{-1}$ and $\mathrm{K}_{2} \mathrm{O} 324 \mathrm{mg} \mathrm{kg}^{-1}$ (Table 1). 
105 C. cardunculus was transplant on May $7^{\text {th }} 2010$ with a density of 1 plant $\mathrm{m}^{-2}$ (Table 2 ). The following 106 factors were studied in a split-plot experimental design with three replicates: two Italian genotypes 107 (Gobbo di Nizza, and Altilis 41, from North/Centre Italy and Sicily, respectively) (Acquadro et al., 108 2012) and seven different fertilization management: 1) $100 \mathrm{~kg} \mathrm{~N} \mathrm{ha}^{-1}$ (N100); 2) $50 \mathrm{~kg} \mathrm{~N} \mathrm{ha}^{-1}$ (N50); 109 compost $30 \mathrm{t} \mathrm{ha}^{-1}(\mathrm{C} 30)$; 4) compost $15 \mathrm{t} \mathrm{ha}^{-1}+25 \mathrm{~kg} \mathrm{~N} \mathrm{ha}^{-1}(\mathrm{C} 15+\mathrm{N} 25)$; 5) defatted seed meal of 110 Brassica carinata (Brassica carinata A. Braun) $3 \mathrm{t} \mathrm{ha}^{-1}$ (DMB3); 6) defatted seed meal of sunflower 111 (Heliantus annus L.) $3 \mathrm{t} \mathrm{ha}^{-1}$ (DMS3) and 7) control unfertilized (N0), considering fertilizer as main 112 plot $\left(69.12 \mathrm{~m}^{2}\right)$ and genotype as sub-plot $\left(34.56 \mathrm{~m}^{2}\right)$.

113 Ammonium nitrate was used as chemical fertilizer. The organic fertilizers showed the following main 114 characteristics: commercial compost from organic fraction of municipal solid waste (GeSeNu $\mathrm{Srl}$, 115 Perugia, Italy) (organic C, $279 \mathrm{~g} \mathrm{~kg}^{-1}$; total $\mathrm{N}, 21 \mathrm{~g} \mathrm{~kg}^{-1}$ ); defatted oilseed meal of B. carinata 116 (organic $\mathrm{C}, 450 \mathrm{~g} \mathrm{~kg}^{-1}$; total $\mathrm{N}, 57 \mathrm{~g} \mathrm{~kg}^{-1}$ ) and defatted oilseed meal of sunflower (organic $\mathrm{C}$, $117450 \mathrm{~g} \mathrm{~kg}^{-1}$; total $\left.\mathrm{N}, 50 \mathrm{~g} \mathrm{~kg}^{-1}\right)$.

118 Four-week-old plants with four leaves were transplanted, $120 \mathrm{~cm}$ apart in rows $80 \mathrm{~cm}$ apart. Each plot 119 consisted of 36 plants. Weeds and pests were controlled according to the production rules of Campania 120 Region, Italy. In particular, weeds were controlled by not-chemical management using mechanical and 121 hand hoeing control. As regards the pathogen and pest control, chemical and organic-admitted 122 fungicides (sulphur) and pesticides (azadirachtin A) were used. The main pests and pathogens observed 123 were aphids, noctuids e mildew. Regarding N100 and N50 in the first year of the trial, C. cardunculus 124 received one third of the nitrogen fertilizer at transplanting and two thirds at the leaf rosette phase. In 125 the following years, half dose was applied at plant sprouting in September and half dose at stalk 126 elongation in April-May. Compost and defatted oilseed meals were administered before transplanting.

127 The crop, since it dries off, was only irrigated in the first year after transplanting and again in 128 September in the second and third year with just light watering, in order to activate sprouting.

129 During the crop cycle (Figure 1) the main weather data were recorded (Table 2). 
130 At harvest, above ground biomass and its partitioning (stalks + leaves and heads) were determined.

131 Crops were harvested when the humidity content was about 13\%. Moisture content of each plant part 132 was calculated by drying samples at $65^{\circ} \mathrm{C}$ in a thermo-ventilated oven until constant weight was 133 achieved.

\subsection{Data collection}

136 During the 3 years of the experiment, the inputs for crop production were minimized and all the 137 agricultural operations were recorded.

138 The plants were grown for dry aboveground biomass, leaving all the heads maturing achenes. At the 139 end of each annual crop cycle, at complete maturation of achenes, number of heads and number of 140 stalks per plant and plant height, were determined. The harvest of above-ground biomass, heads 141 enclosed, was carried out on $7^{\text {th }}$ September 2011, $28^{\text {th }}$ August 2012 and $16^{\text {th }}$ September 2013. Ten 142 plants standing in the middle of each plot were harvested; plants bordering each side of a plot were 143 discarded. The plants were cut at ground level and immediately were weighed in open field, in order to 144 determine the fresh weight (f. w.) of biomass components (stalks + leaves and heads). In the laboratory, 145 the moisture content was measured by weighing $100 \mathrm{~g}$ of plant material in a precalibrated aluminum 146 container and placing it in a thermoventilated oven at $105{ }^{\circ} \mathrm{C}$ until constant weight was reached. 147 Biomass yield were expressed as $\mathrm{g} \mathrm{m}^{-2}$ of dry weight (d.w.). The stalks plus leaves and heads incidence 148 on total above-ground biomass was calculated.

\section{$150 \quad 2.4$ Environmental assessment methodology}

151 Greenhouse gas (GHG) emissions valuation by Life Cycle Assessment (LCA) was performed. The 152 LCA analysis was used, considering entire life cycle at farm gate, providing a method to assess 153 different fertilization performances. One hectare (ha) of cultivation and 1 ton ( $\mathrm{t}$ ) of harvest biomass (d. 154 w.) were used as functional units (FU) to study the potential environmental impacts of cardoon 155 production. Global warming potential (GWP) was adopted as the impact category for this study. 
156 Functional units expressed in $\mathrm{kg} \mathrm{CO}_{2}$-equivalents $\left(\mathrm{CO}_{2}\right.$-eq), were obtained using Tier 2 methodologies 157 recommended by the IPCC (2006).

158 The study considered the process from the soil tillage to the harvest time of the crop.

159 Most data related to energy consumption, were recorded during the crop cycles; in addition, available 160 data were also used as electrical energy (EPA, 2014; Pehnt, 2006) gasoline, lubrificant (Furuholt, 1995;

161 Cuevas, 2005) and fertilizer production (Mazzoncini et al., 2015; Skowrońska \& Filipek, 2013; Hesq \& 162 Jenssen, 2010). Emissions from diesel combustion were referred to EEA (2013) guidebook. Direct and 163 indirect $\mathrm{N}_{2} \mathrm{O}$ emissions from fertilizers and residues were calculated following IPCC (2006) tier 1, 164 considering a reduction of $28 \%$ observed for solid organic fertilizers (Aguilera, Lassaletta, Sanz165 Cobena, Garnier, \& Vallejo, 2013). Impact of seeds, seedlings, pesticides and fungicides production, as 166 well as manufacture and maintenance of farm's equipment, their transport and their waste management, 167 were omitted in the analysis due to the same contribution on the different fertilization treatments 168 (Meisterling, Samaras, \& Schweizer, 2009).

$170 \quad 2.5$ Data analysis

171 Data were analyzed using analysis of variance (ANOVA). Means were statistically separated on the 172 basis of Tukey test, when the ' $\mathrm{F}$ ' test of ANOVA for treatment was significant at least at the 0.05 173 probability level. Experimental data were processed for a principal component analysis (PCA) using 174 PLS Toolbox software (Eigenvector Research Inc, Wenatchee, WA, USA), in order to evaluate the 175 existing relationships with original variables.

\section{3. RESULTS AND DISCUSSION}

178 During the 3 years of the trial, monthly temperature and rainfall were measured by a weather station in 179 the experimental field. The site was mainly characterized by air temperatures, with minimum values 180 ranging from 10.0 to $12.4{ }^{\circ} \mathrm{C}$ and maximum values ranging from 17.2 to $21.8{ }^{\circ} \mathrm{C}$. There was 
181 considerable variability in rainfall and its distribution from year to year. The mean annual amounts of 182 rainfall observed over the 3-years, were $670 \mathrm{~mm}, 990 \mathrm{~mm}$ and $360 \mathrm{~mm}$, respectively.

183

\section{4}

185

186

187

188

189

190

191

192

193

194

195

196

197

198

199

200

$201(+46 \%)$ compared to the unfertilized treatment. However, the other fertilizers showed similar values to

202 N100, except for DMB3 and N0. "Altilis 41" recorded the higher value (+16\%) compared to "Gobbo di

203 Nizza". The first year was the more productive $(+18 \%$ and $+54 \%)$ respect to the second and the third 204 ones, respectively.

205 Regarding the eight of the plants, no effects were recorded by fertilization treatments, while "Gobbo di 206 Nizza" showed the higher value $(+5 \%)$ than "Altilis 41 ". The effect of the year highlighted a similar 
207 trend noticed for the number of heads. In the first year, was recorded the highest value $(+5 \%$ and $208+26 \%$ ) compared to the second and the third ones.

209 About the most important trait, aboveground biomass, N100 recorded the higher value of stalks and 210 leaves dry weight (+73\%) followed by DMS3 (+14\%) compared to unfertilized treatment, respectively. 211 Genotype "Altilis 41" showed the higher value $(+13 \%)$ and, in the first year, was recorded the highest 212 production, $+62 \%$ and $+100 \%$, compared to the second and the third ones, respectively.

213 No differences were recorded for heads dry weights among the different fertilization treatments, while 214 genotype "Altilis 41" highlighted the higher value (+46\%) than "Gobbo di Nizza"; the first year was 215 the most productive $(+24 \%$ and $+113 \%)$ than the second and the third ones, respectively.

216 Total dry weight of cardoon was affected by fertilizer, genotype and year, showing a similar trend 217 reported for stalks and leaves dry weighs. When ammonium nitrate was applied at $100 \mathrm{~kg} \mathrm{ha}^{-1}$ (N100) 218 total dry weight production increased by $65 \%$ respect to N0 (Table 3). DMS3 and N50 produced a 219 similar effect to $\mathrm{N} 100$ but at lower level $(+14 \%$ and $+11 \%$, respectively) compared to N0. Genotype 220 "Altilis 41" highlighted the higher value $(+21 \%)$ than "Gobbo di Nizza"; the first year was the most 221 productive $(+51 \%$ and $+100 \%)$ than the second and the third ones, respectively.

222 Our data confirming the hypothesis reported by Portis et al. (2005) who highlighted that cultivated 223 cardoon behaviors can be considered as an annual crop. Moreover, as showed by Raccuia \& Melilli 224 (2007) the radical apparatus progressively grows deeper, hence the differences due to the age of the 225 crop were more obvious after the first year of cultivation.

226 Another important trait in biomass production is the biomass partitioning. The fertilization N50 227 increased the biomass allocated to heads, showing the highest value $(+11 \%)$ respect to the general 228 average. Genotype "Altilis 41 " performed better than "Gobbo di Nizza", allocating $+20 \%$ of the total 229 biomass in the heads. In the second year was registered the highest value of allocation $(+27 \%$ and $230+40 \%$ ) respect to of the first and the third year, respectively. 
231 Finally, regarding the average weight of the heads, no effects were recorded by the different fertilizers. 232 Genotype "Altilis 41" performed better than "Gobbo di Nizza" (+26\%) while, in the second year, was 233 recorded the highest value $(+5 \%$ and $+36 \%)$ respect to the first and the last ones, respectively.

234 Summarizing our results, DMS3 could be a sustainable organic fertilizer for the production of 235 cultivated cardoon. Similar results were obtained by Mazzoncini et al. (2015) working on vegetable 236 crops such as lettuce, chard and spinach. The lower agronomical performance of DMB3 was putatively 237 due to the content of glucosinolates that may reduce the availability of nitrogen and/or inhibit the effect 238 on nitrification processes (Mazzoncini et al., 2015).

239 Zaccardelli et al. (2013) reported a significant positive response of the soil enzymatic activities due to 240 the addition of seed meals for the eggplant production, indicating a beneficial effect on soil quality. In 241 addition, Zaccardelli et al. (2013) showed that defatted oilseed meals, compared to compost, 242 highlighted an increase of soil enzymatic activities only in the first two months after application, 243 reflecting the rate of release of nutrients, such as mineral fertilizers. Hence, the lower release of 244 nutrients showed by compost could be negatively affects the cardoon production in the present work. 245 However, further investigations are required to confirm this hypothesis.

246 In the preset study, "Altilis 41" performed better than "Gobbo di Nizza", reflecting its suitability for the 247 investigated environment (Acquadro et al., 2012).

248 About biomass production, the results recorded in the present study are in agreement with Fernández 249 (1998), that reported a biomass production of C. cardunculus from 10 to $20 \mathrm{t}$ of d.w. ha ${ }^{-1}$ year $^{-1}$, if the 250 crop is well established and rainfall is about $500 \mathrm{~mm}_{\text {year }}{ }^{-1}$. Also González et al. (2004) recorded an 251 aerial biomass production (about $11 \mathrm{t} \mathrm{ha}^{-1}$ of $\mathrm{d}$. w.) similar to our results.

252 Moreover, our results regarding biomass production, dry weight distribution, number of heads and 253 plant height, were in agreement with those reported in an interesting study conducted by Ierna \& 254 Mauromicale (2010). The authors cropped genotype "Cardo gigante di Romagna" under low input crop 255 management applying $80 \mathrm{~kg} \mathrm{ha}^{-1}$ of nitrogen as ammonium nitrate. 
256 On the other hand, comparing our results with those obtained under high input management, the 257 maximum yield recorded in the present study was lower (about $-50 \%$ ) respect that one reported by 258 Mantineo et al. (2009) who, however, used a different genotype (Cardo gigante inerme) with high 259 irrigation and fertilizer treatment (irrigation as $75 \%$ of evapotraspirated water and fertilization as 100 $260 \mathrm{~kg} \mathrm{ha}^{-1}$ of nitrogen). Nonetheless, similar to our results, a lower aboveground biomass yield (less than $2611 \mathrm{tha}{ }^{-1}$ of d. w.) in the last year of cultivation was registered.

262 Cardoon needs less nitrogen than many other crops. In many field experiments, high biomass yields 263 were attainable under fertilization dressings from 0 up to $50 \mathrm{~kg}$ of $\mathrm{N} \mathrm{ha}^{-1}$ (Grammelis et al., 2008). In 264 fact, an interesting point was observed with compost fertilization. In the present study, $30 \mathrm{t} \mathrm{ha}^{-1}$, 265 corresponding to about $600 \mathrm{~kg} \mathrm{~N} \mathrm{ha}^{-1}$, were applied and a biomass production similar to unfertilized 266 treatment was registered.

\subsection{Relationships among the recorded parameter, fertilization, genotype and years}

269 The correlation between recorded parameters, genotype, fertilization treatments and year was studied 270 by means of PCA. Figure 2 reports the biplots of the PCA models calculated tacking in account the data 271 recorded during the 3-year of cultivations. In the PCA model, the two first components represented 272 more than half of variation in the datasets, PC1 accounts for $30.14 \%$ and PC2 for $27.51 \%$. It was no 273 possible to identify clear separations into clusters: therefore, the results are described in relation to the 274 most important parameter, such as total dry weight. In general, total dry weight, average weight of 275 heads, dry weight of heads and biomass allocated to heads, are highly associated, since they are close 276 each other (Figure 2).

277 PC1 clearly highlights the effects of the number of stalks and the biomass allocated to stalks plus leaves 278 on total dry weight, while PC2 is mainly related to the difference between the morphological and 279 yielding traits regarding the heads.

280 Year 2012 was in the middle between years 2011 and 2013, overlapping in some points. This fact 281 confirms the annual variation showed in Table 3. The yearly variability due to different weather 
282 condition, as reported in the present study, was highlighted also in other studies conducted in a similar 283 area (Rinaldi, Convertini, \& Elia, 2007; Ronga et al., 2015). Moreover, the differences recoded 284 between the two growing seasons were putatively ascribed at the different weather condition between 285 the three years. In fact, 2013 was drier and colder than 2012 and 2011 (Table 2), probably causing the 286 longest crop cycle (Table 2) and the lowest biomass production (Table 3). In fact, the production of 287 aboveground biomass on C. cardunculus depends on the presence of water in the soil, especially in dry 288 conditions and the adequate fertilization of the crop. In experiences carried out in several countries of 289 the Mediterranean zone, was highlighted a high correlation between the rainfall of the year and the total 290 biomass production of cardoon, especially with the rainfall occurred during Spring (González et al., $2912004)$.

292

\subsection{Environmental impact}

294 The GWP of cardoon production per area is reported in Figure 3a; the higher impact recorded in the 295 present study was mainly due to GHG emissions to produce fertilizers, followed by direct and indirect 296 emission and, then, by agricultural operations (data not shown). Among treatments, N0 had the lowest 297 impact per hectare, followed by N50 and defatted oilseed meals (Figure 3a). On the other hand, the 298 impact per total biomass was obviously lower for unfertilized treatment than fertilized ones. In fact, 299 opposite results were observed using $1 \mathrm{t}$ of harvested biomass (d. w.) as FU (Figure 3b). Treatment C30 300 achieved a higher impact $(+230 \%$ on the average impact), due to low yield $(-10 \%$ on the average yield) 301 (Table 3). An interesting result was showed by the impact of defatted oilseed meal of sunflower meal 302 that was lower per unit area compared to N100 treatment and remained similar when computed per t of 303 harvest d. w., showing about $240 \mathrm{~kg} \mathrm{CO}_{2}$ eq per $\mathrm{t}$ of $\mathrm{d}$. w.

304 In particular, among the investigated organic fertilizers, DMS3 caused the lowest impact per hectare 305 and total biomass, and some similar results were reported by Mazzoncini et al. (2015) on vegetables 306 crop. 
307 Moreover, our results regarding GWP, both per cropped area and crop yield, are comparable with those 308 reported by Cocco et al. (2014) and Razza et al. (2015) who investigated the life cycle assessment of 309 cardoon cropped in Southern Europe and Sardinia and Sicily, respectively.

\section{4. Conclusions}

312 Following 3 years of observation, organic fertilizer cloud be a sustainable approach for the cardoon 313 production in the environment of Southern Italy. Defatted oilseed meal of sunflower may be properly 314 used as organic fertilizers for cardoon production, ensuring yields comparable with those obtained 315 using mineral nitrogen fertilizer. The present study showed the higher efficacy of defatted oilseed meal 316 of sunflower in sustaining aboveground biomass yield when compared to $B$. carinata meal and 317 compost. The GWP of defatted oilseed meal of sunflower was also better than the $B$. carinata meal and 318 compost footprints. Overall, our findings confirmed the high value of oilseed meals as a sustainable 319 alternative to mineral fertilizers and an important nutrient source also for cardoon production. From the 320 agricultural point of view, the success of the application of defatted oilseed meal of sunflower increase 321 the agricultural sustainability. In conclusion, the potential of cardoons as energy crop in Mediterranean 322 cropping systems under sustainable inputs managements is confirmed in terms of aboveground biomass 323 production. However, future research investments are required to increase and optimize yield and GWP 324 of cardoon production.

\section{Acknowledgements}

327 This work was supported by the [Mipaaf (Ministero delle Politiche Agricole, Alimentari e Forestali 328 Italy)]. The trials were performed as activities of the Project "Costituzione e valutazione 329 dell'adattabilità di genotipi di Cynara cardunculus per la produzione di biomassa e biodiesel in 330 ambiente mediterraneo" (CYNERGIA). The authors acknowledge prof. Sergio Lanteri and 331 Mauromicale for to have provided the genotypes of cardoon used and Bruno D'Onofrio and Tommaso 332 Gallingani, who helped in management, sampling and data analyses. 


\section{References}

335 Acquadro, A., Portis, E., Scaglione, D., Mauro, R. P., Campion, B., Falavigna, A., Zaccardelli, M., 336 Ronga, D., Perrone, D., Mauromicale, G., \& Lanteri, S. (2012). CYNERGIA project: exploitability of 337 Cynara cardunculus L. as energy crop. Acta Horticulturae, 983, 109-115.

338 Aguilera, E., Lassaletta, L., Sanz-Cobena, A., Garnier, J., \& Vallejo, A. (2013). The potential of 339 organic fertilizers and water management to reduce N2O emissions in Mediterranean climate cropping 340 systems. A review. Agriculture, Ecosystems \& Environment, 164, 32-52.

341 Angelini, L.G., Ceccarini, L., Nassi o Di Nasso, N., \& Bonari, E. (2009). Long-term evaluation of 342 biomass production and quality of two cardoon (Cynara cardunculus L.) cultivars for energy use. 343 Biomass \& Bioenergy, 33, 810-816.

344 Cajarville, C., Gonzalez, J., Repetto, J.L., Rodrìguez, C., \& Martìnez, A. (1999). Nutritive value of 345 green forage and crop by-products of C. cardunculus. Annales de Zootechnie, 48, 353-365.

346 Cocco, D., Deligios, P. A., Ledda, L., Sulas, L., Virdis, A., \& Carboni, G. (2014). LCA study of 347 oleaginous bioenergy chains in a mediterranean environment. Energies, 7, 6258-6281.

348 Cosentino, S.L., Copani, V., Mantineo, M., Patané, C., \& D’Agosta, G. (2008). Agronomic, energetic 349 and environmental aspects of biomass energy crops suitable for Italian environments. Italian Journal of 350 Agronomy, 2, 81-95.

351 Cuevas, P. (2005). Comparative life cycle assessment of biolubricants and mineral based lubricants. 352 Dissertation, University of Pittsburgh.

353 EEA (2013). EMEP/EEA emission inventory guidebook (2013) Copenhagen, Denmark.

354 EPA (2014). United States Environmental Protection Agency. Emission factors for greenhouse gas 355 inventories available at:http:/www.epa.gov/climateleadership/documents/emission-factors.pdf 356 Fernández, J. (1998). Cardoon. Energy Plant Species. James \& James Science Publishers Ltd., London, $357 \quad 113-117$ 
358 Foti, S., Mauromicale, G., Raccuia, S.A., Fallico, B., Fanella, F., \& Maccarone, E. (1999). Possible 359 alternative utilisation of Cynara spp. Part I. Biomass, grain yield and chemical composition of grain. 360 Industrial Crops and Products, 10, 219-228.

361 Foti, S., \& Cosentino, S.L. (2001). Colture erbacee annuali e poliennali da energia. Rivista di 362 Agronomia, 35, 200-215.

363 Furuholt, E. (1995). Life cycle assessment of gasoline and diesel. Resources, Conservation and 364 Recycling, 14, 251-263.

365 Gherbin, P., Monteleone, M., \& Tarantino, E. (2001). Five years evaluation on cardoon (Cynara 366 cardunculus L. var altilis) biomass production in a Mediterranean environment. Italian Journal of 367 Agronomy, 5, 11-19.

368 Gominho, J., Fernandez, J., \& Pereira, H. (2001). Cynara cardunculus L.-a new fibre crop for pulp 369 and paper production. Industrial Crops and Products, 13, 1-10.

370 González, J.F., González-García, C.M., Ramiro, A., González, J., Sabio, E., Gañán, J., \& Rodríguez, 371 M.A. (2004). Combustion optimisation of biomass residue pellets for domestic heating with a mural 372 boiler. Biomass \& Bioenergy, 27, 145-154.

373 Grammelis, P., Malliopoulou, A., Basinas, P., \& Danalatos, N.G. (2008). Cultivation and 374 characterization of Cynara cardunculus for solid biofuels production in the Mediterranean region. 375 International Journal of Molecular Sciences, 9, 1241-1258.

376 Hesq, Y., \& Jenssen, T. K. (2010). Calculation of Carbon Footprint of Fertilizer Production.

377 Ierna, A., \& Mauromicale, G. (2010). Cynara cardunculus L. genotypes as a crop for energy purposes 378 in a Mediterranean environment. Biomass \& Bioenergy, 34, 754-760.

379 IPCC (2006). Guidelines for national greenhouse gas inventories. Agriculture, Forestry and Other Land 380 Use, vol. 4, Intergovernmental Panel on Climate Change, IGES, Japan (2006).

381 Jimenez-Escrig, A., Dragsted, L.O., Daneshvar, B., Pulido, R., \& Saura-Calixto, F. (2003). In vitro 382 antioxidant activities of edible artichoke (Cynara scolymus L.) and effect on biomarkers of antioxidants 383 in rats. Journal of Agricultural and Food Chemistry, 51, 5540-5545. 
384 Kraft, K. (1997). Artichoke leaf extract: recent findings reflecting effects on lipid metabolism, liver and 385 gastrointestinal tracts. Phytomedicine, 4, 369-378.

386 Lapuerta, M., Armas, O., Ballesteros, R., \& Fenàndez, J. (2005). Diesel emissions from biofuels 387 derived from Spanish potential vegetable oils. Fuel, 84, 773-778.

388 Lewandowski, I., \& Schmidt, U. (2006). Nitrogen, energy and land use efficiencies of miscanthus, reed 389 canary grass and triticale as determined by the boundary line approach. Agriculture, Ecosystems \& 390 Environment,112, 335-346.

391 Maccarone, E., Fallico, B., Fanella, F., Mauromicale, G., Raccuia, S.A., \& Foti, S. (1999). Possible 392 alternative utilization of Cynara spp. Part II. Chemical characterisation of their grain oil. Industrial 393 Crop and Products, 10, 229-237.

394 Mantineo, M., D’agosta, G. M., Copani, V., Patanè, C., \& Cosentino, S.L. (2009). Biomass yield and 395 energy balance of three perennial crops for energy use in the semi-arid Mediterranean environment. 396 Field Crops Research, 114, 204-213.

397 Mazzoncini, M., Antichi, D., Tavarini, S., Silvestri, N., Lazzeri, L., \& D’Avino, L. (2015). Effect of 398 defatted oilseed meals applied as organic fertilizers on vegetable crop production and environmental 399 impact. Industrial Crop and Products, 75, 54-64.

400 Meisterling, K., Samaras, C., \& Schweizer, V. (2009). Decision to reduce greenhouse gases from 401 agriculture and product transport: LCA case study of organic and conventional wheat. Journal of 402 Cleaner Production, 17, 222-230.

403 Ochoa, M.J., \& Fandos, A. (2004). Evaluation of vegetable cardoon (Cynara cardunculus L.) 404 populations for biomass production under rain-feed conditions. Acta Horticulturae, 660, 235-239.

405 Pehnt, M. (2006). Dynamic life cycle assessment (LCA) of renewable energy technologies. Renewable 406 Energy, 31, 55-71.

407 Piscioneri, I., Sharma, N., Baviello, G., \& Orlandini, S. (2000). Promising industrial energy crop, 408 Cynara cardunculus: a potential source for biomass production and alternative energy. Energy 409 Conversion and Management, 41, 1091-1105. 
410 Portis, E., Barchi, L., Acquadro, A., Macua, J.I., \& Lanteri, S. (2005). Genetic diversity assessment in 411 cultivated cardoon by AFLP (amplified fragment length polymorphism) and microsatellite markers

412 Plant Breeding, 124, 299-304.

413 Raccuia, S.A., \& Melilli, M.G. (2007). Biomass and grain oil yields in Cynara cardunculus L. 414 genotypes grown in a Mediterranean environment. Field Crops Research, 101, 187-197.

415 Razza, F., Sollima, L., Falce, M., Costa, R.M.S., Toscano, V., Novelli, A., Ciancolini, A., \& Raccuia, 416 S.A. (2015). Life cycle assessment of cardoon production system in different areas of Italy. Acta 417 Horticulturae, 1147, 329-334.

418 Rinaldi, M., Convertini, G., \& Elia, A. (2007). Organic and mineral nitrogen fertilization for processing 419 tomato in Southern Italy. Acta Horticulturae, 758, 241-248.

420 Ronga, D., Lovelli, S., Zaccardelli, M., Perrone, D., Ulrici, A., Francia, E., Milc, J. \& Pecchioni, N. 421 (2015). Physiological responses of processing tomato in organic and conventional Mediterranean 422 cropping systems. Scientia Horticulturae, 190, 161-172.

423 Royal Society (2008). Sustainable biofuels: prospects and challenges. Policy document‘1/08.

424 Skowrońska, M., \& Filipek, T. (2013). Life cycle assessment of fertilizers: a review. International 425 Agrophysics, 28, 101-110.

426 USDA (2006). Keys to Soil Taxonomy United State Department of Agriculture, 10thed. Natural 427 Resources Conservation Service (NRCS).

428 Zaccardelli, M., Villecco, D., Celano, G., \& Scotti, R. (2013). Soil amendment with seed meals: Short 429 term effects on soil respiration and biochemical properties. Applied Soil Ecology, 72, 225-231. 
Table 1. Soil characteristics of the investigated field

\begin{tabular}{lc}
\hline $\begin{array}{l}\text { Soil } \\
\text { characteristics }\end{array}$ & \\
\hline Sand (\%) & 26.8 \\
Silt (\%) & 40.8 \\
Clay (\%) & 32.4 \\
pH & 7.8 \\
Limestone (\%) & 2.4 \\
K$_{\mathbf{2}}$ O (mg/Kg) & 324.0 \\
$\mathbf{P}_{\mathbf{2}} \mathbf{O}_{\mathbf{5}}$ (mg/kg) & 126.0 \\
N. tot. (\%o) & 1.3 \\
Organic matter & 1.6 \\
(\%) & 18.3 \\
CSC (meq/100 g) & \\
\hline
\end{tabular}


Table 2. Transplant and harvest dates and weather conditions recorded during the three trial growing seasons

\begin{tabular}{|c|c|c|c|c|c|c|}
\hline Year & $\begin{array}{l}\text { Location } \\
\text { (Lat Long) }\end{array}$ & $\begin{array}{c}\text { Transplant } \\
\text { date }\end{array}$ & $\begin{array}{c}\text { Harvest } \\
\text { date }\end{array}$ & $\begin{array}{c}\text { Average } \\
\text { T min } \\
\left({ }^{\circ} \mathrm{C}\right) \\
\end{array}$ & $\begin{array}{c}\text { Average } \\
\text { T max } \\
\left({ }^{\circ} \mathbf{C}\right) \\
\end{array}$ & $\begin{array}{c}\text { Total } \\
\text { rainfall } \\
(\mathbf{m m})\end{array}$ \\
\hline 2011 & $\begin{array}{c}\text { CRA-ORT } \\
40^{\circ} 35^{\prime} 03.8^{\prime \prime N}, \\
14^{\circ} 58^{\prime} 48.6^{\prime \prime} \mathrm{E}\end{array}$ & $07 / 05 / 2010$ & $07 / 09 / 2011$ & 12.4 & 21.8 & 670 \\
\hline 2012 & $\begin{array}{c}\text { CRA-ORT } \\
40^{\circ} 35^{\prime} 03.8^{\prime \prime} \mathrm{N}, \\
14^{\circ} 58^{\prime} 48.6^{\prime \prime} \mathrm{E}\end{array}$ & - & $28 / 08 / 2012$ & 11.4 & 21.0 & 990 \\
\hline 2013 & $\begin{array}{c}\text { CRA-ORT } \\
40^{\circ} 35^{\prime} 03.8^{\prime \prime N}, \\
14^{\circ} 58^{\prime} 48.6^{\prime \prime} \mathrm{E}\end{array}$ & - & $16 / 09 / 2013$ & 10.0 & 17.2 & 360 \\
\hline Average & & & & 11.3 & 20.0 & 673 \\
\hline
\end{tabular}


Table 3. Yield-related agronomical traits, at harvest time, of two cardoon cultivars, over three years of cultivation in Southern Italy.

\begin{tabular}{|c|c|c|c|c|c|c|c|c|c|}
\hline Source of Variation & $\begin{array}{c}\text { Number of } \\
\text { stalk } \\
\left(\text { no. } \text { plant }^{-2}\right)\end{array}$ & 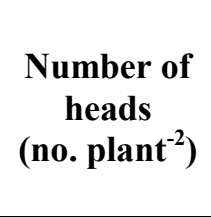 & $\begin{array}{l}\text { Height } \\
\text { of plant } \\
\text { (m) }\end{array}$ & $\begin{array}{r}\text { Dry weigh } \\
\text { stalk and le } \\
\left(\mathrm{g} \mathrm{m}^{-2}\right)\end{array}$ & & $\begin{array}{c}\text { Dry } \\
\text { weight of } \\
\text { heads } \\
\left(\mathrm{g} \mathrm{m}^{-2}\right)\end{array}$ & $\begin{array}{c}\text { Total dry } \\
\text { weight } \\
\left(\mathrm{g} \mathrm{m}^{-2}\right)\end{array}$ & $\begin{array}{c}\text { Fraction } \\
\text { of total } \\
\text { dry } \\
\text { weights } \\
\text { to heads }\end{array}$ & $\begin{array}{l}\text { Average } \\
\text { weight of } \\
\text { heads } \\
\text { (g) }\end{array}$ \\
\hline \multicolumn{10}{|l|}{ Fertilizer } \\
\hline N100 & 2.7 & 13.5 & 2.4 & 965.6 & $\mathrm{a}$ & 300.1 & 1265.2 & 23.3 & 21.5 \\
\hline N50 & 2.5 & 10.8 & 2.2 & 617.7 & $\mathrm{~b}$ & 246.1 & $864.2 \quad \mathrm{ab}$ & $29.4 \quad \mathrm{a}$ & 22.1 \\
\hline $\mathrm{C} 30$ & 2.4 & 9.6 & 2.1 & 613.5 & $\mathrm{~b}$ & 200.8 & 814.4 & $24.3 \quad b c$ & 19.8 \\
\hline $\mathrm{C} 15+\mathrm{N} 25$ & 2.4 & 10.1 & 2.2 & 571.9 & $\mathrm{~b}$ & 222.2 & 794.6 & $27.2 \mathrm{abc}$ & 21.1 \\
\hline DMB3 & 2.3 & 8.9 & 2.1 & 579.2 & $\mathrm{~b}$ & 200.9 & 780.1 & $25.9 \quad \mathrm{abc}$ & 21.2 \\
\hline DMS3 & 2.3 & 10.6 & 2.2 & 633.3 & $a b$ & 241.1 & 874.6 & $27.8 \quad a b$ & 21.6 \\
\hline No & 2.2 & 9.2 & 2.1 & 556.3 & $\mathrm{~b}$ & 206.8 & 762.9 & $26.7 \mathrm{abc}$ & 21.7 \\
\hline P-value & n.s. & $<0.05$ & n.s. & $<0.05$ & & ns & $<0.05$ & $<0.05$ & $\mathrm{~ns}$ \\
\hline \multicolumn{10}{|l|}{ Cultivar } \\
\hline Gobbo di Nizza & 2.7 & 9.6 & 2.2 & 609.4 & $\mathrm{~b}$ & 187.9 & 797.3 & 24.0 & 18.8 \\
\hline Altilis 41 & 2.1 & 11.1 & $2.1 \quad b$ & 687.5 & $\mathrm{a}$ & 274.4 & 961.4 & 28.8 & 23.7 \\
\hline p-value & $<0.001$ & $<0.01$ & $<0.01$ & \multicolumn{2}{|l|}{$<0.05$} & $<0.001$ & $<0.001$ & $<0.001$ & $<0.001$ \\
\hline \multicolumn{10}{|l|}{ Year } \\
\hline 2011 & 1.6 & 12.5 & 2.4 & 914.6 & $\mathrm{a}$ & 305.4 & 1220.0 & 24.9 & 22.9 \\
\hline 2012 & 2.7 & 10.6 & 2.3 & 563.5 & $\mathrm{~b}$ & 245.1 & 808.6 & 31.6 & 24.0 \\
\hline 2013 & 2.8 & 8.1 & 1.9 & 466.7 & $\mathrm{~b}$ & 143.0 & 609.5 & 22.6 & 16.9 \\
\hline P-value & $<0.001$ & $<0.001$ & $<0.001$ & \multicolumn{2}{|l|}{$<0.001$} & $<0.001$ & $<0.001$ & $<0.001$ & $<0.001$ \\
\hline
\end{tabular}



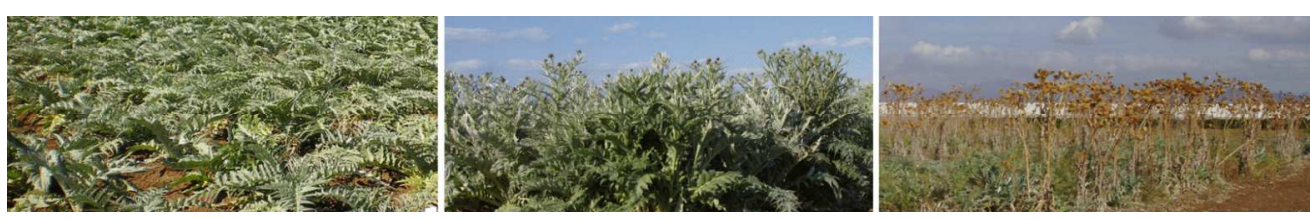


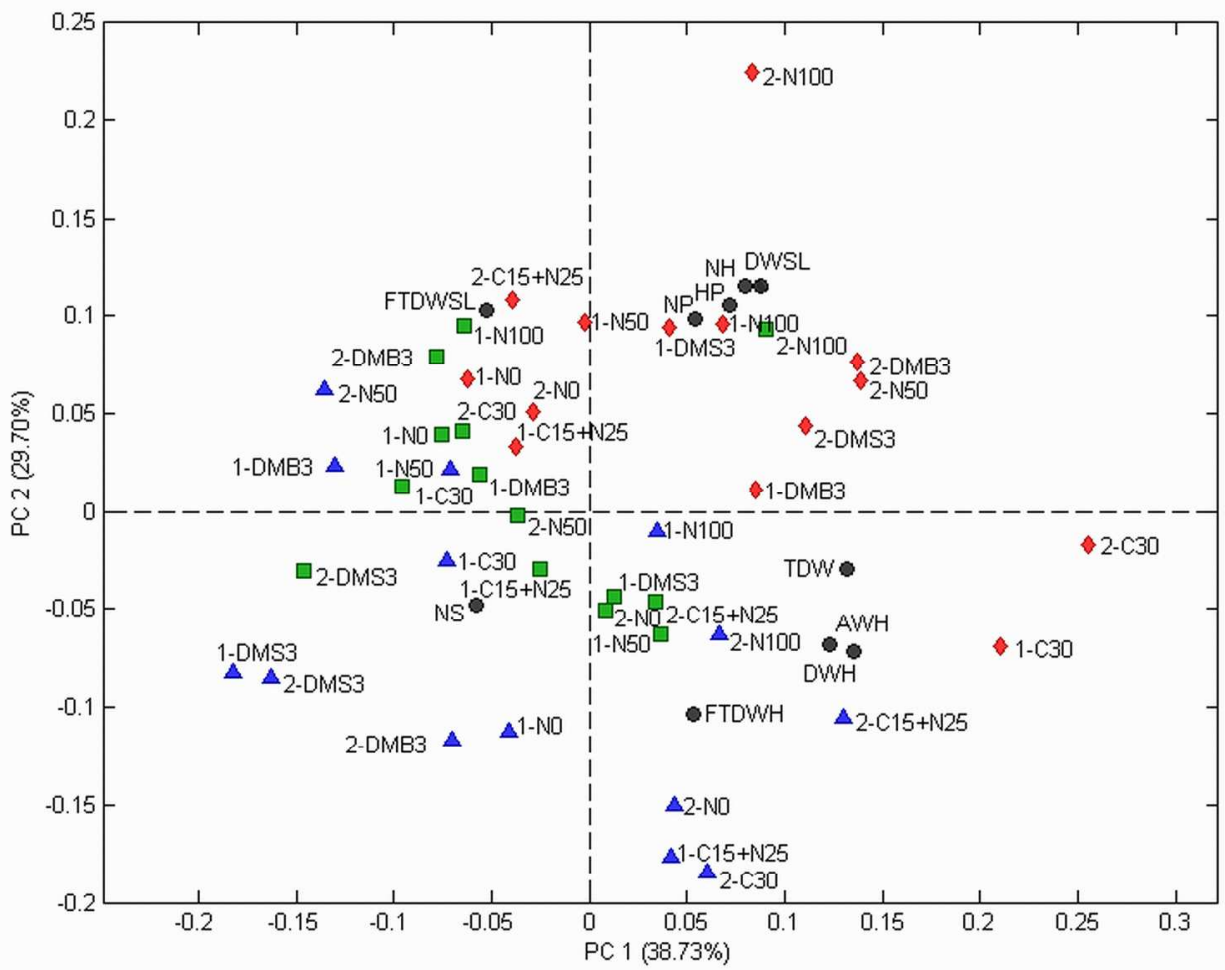

$1041 \times 815 \mathrm{~mm}(72 \times 72 \mathrm{DPI})$ 
a)
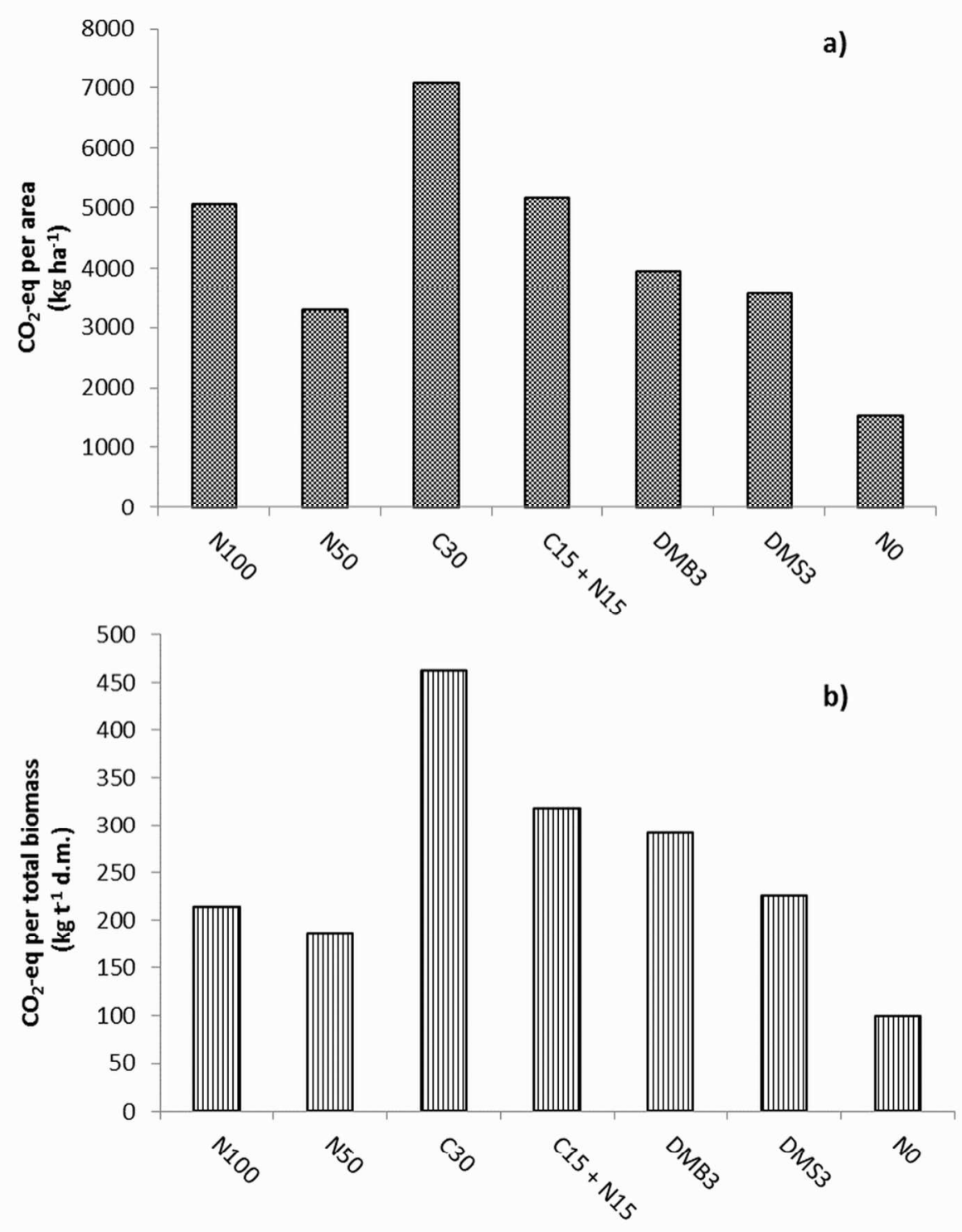

$833 \times 1013 \mathrm{~mm}(72 \times 72 \mathrm{DPI})$ 
Figure 1. Cardoon growth cycle: vegetative stage (on the left), reproductive stage (on the middle) and harvest stage (on the right).

Figure 2. Ordination biplots of principal component analysis outputs. Labels in the graph indicate the investigated treatments, genotypes and years (red diamonds $=2011$, green square $=2012$ and blue triangle $=2013$ ) and recorded traits (represented by black circles). $1-=$ Gobbo di Nizza. 2- = Altilis 41. $\mathrm{N} 100=100 \mathrm{~kg} \mathrm{~N} \mathrm{ha}^{-1} ; \mathrm{N} 50=50 \mathrm{~kg} \mathrm{~N} \mathrm{ha}^{-1} ; \mathrm{C} 30=$ compost $30 \mathrm{tha}^{-1} ; \mathrm{C} 15+\mathrm{N} 25=$ compost $15 \mathrm{tha}^{-1}+$ $25 \mathrm{~kg} \mathrm{~N} \mathrm{ha}^{-1}$; DMS3 = defatted meal of sunflower $3 \mathrm{t} \mathrm{ha}^{-1}$; DMB3 = defatted meal of brassica carinata 3 $\mathrm{tha}^{-1} ; \mathrm{N} 0=0 \mathrm{~kg} \mathrm{~N} \mathrm{ha}{ }^{-1} . \mathrm{NS}=$ numbers of stalks; FTDWH $=$ fraction of total dry weight to heads; $\mathrm{DWH}=$ dry weight of heads; AWH = average fresh weights of heads; TWD = total dry weight of plant; FTWDSL $=$ fraction of total dry weight to stalks; NP = number of plants; $\mathrm{HP}=$ height of plants; $\mathrm{NH}=$ number of heads; DWSL $=$ dry weights of stalks.

Figure 3. Impact on global warming per: (a) area unit $\left(\mathrm{CO}_{2}\right.$-eq per hectare); (b) total biomass unit (CO2-eq per kg of total crop aboveground dry matter). Crops were fertilized with $\mathrm{N} 100=100 \mathrm{~kg} \mathrm{~N}^{-}$ ${ }^{1} ; \mathrm{N} 50=50 \mathrm{~kg} \mathrm{~N} \mathrm{ha}{ }^{-1} ; \mathrm{C} 30=$ compost $30 \mathrm{tha}^{-1} ; \mathrm{C} 15+\mathrm{N} 25=$ compost $15 \mathrm{tha}^{-1}+25 \mathrm{~kg} \mathrm{~N} \mathrm{ha}^{-1}$; DMS3 $=$ defatted meal of sunflower $3 \mathrm{tha}^{-1}$; DMB3 $=$ defatted meal of brassica carinata $3 \mathrm{t} \mathrm{ha}^{-1} ; \mathrm{N} 0=0 \mathrm{~kg} \mathrm{~N}$ $\mathrm{ha}^{-1}$. 